\title{
SKRINING BAKTERI ANTAGONIS RALSTONIA SP., PENYEBAB PENYAKIT LAYU BAKTERI PISANG DI LAMPUNG
}

\author{
Titik Nur Aeny ${ }^{1}$, Radix Suharjo $^{1}$, dan Subli Mujim ${ }^{1}$
}

\begin{abstract}
Screening on Antagonistic Bacteria of Ralstonia sp., the Causal Agent of Banana Bacterial Wilt in Lampung. This study was conducted on May to October 2006. This study was aimed to screen and collect potential bacterial antagonists toward Ralstonia sp., the causal agent of banana bacterial wilt; to identify the collected potential antagonists, and to test the capability of the bacterial antagonist in vitro. A survey to collect soil samples was conducted in 5 districts in Lampung, namely Bandar Lampung, Lampung Selatan, Tanggamus, Lampung Utara, Lampung Tengah, and Lampung Timur. Identification and test of the antagonistic capability was done in the Plant Disease Laboratory, University of Lampung. Identification of the antagonist bacteria was done through several biochemical tests i.e. : gram reaction, hypersensitive reaction on tobacco, oxidative-fermentative, colony color on YDC medium, fluoresence, nitrate reduction, gelatin reduction and starch hydrolise. The results were then compared to the guidelines of bacterial identification. Twenty one soil samples were collected from those surveyed areas to isolate antagonist bacteria, and 104 isolates were found to be antagonistic to Ralstonia sp.. Based on the biochemical tests, it was showed that 59 isolates were in the group of fluorecent pseudomonad and 45 ones were still unidentified. Out of 104 isolates found, 41 isolates have the ability to inhibit the growth of Ralstonia sp.
\end{abstract}

Key words: antagonist bacteria, inhibition, Ralstonia sp, banana bacterial wilt

\section{PENDAHULUAN}

Salah satu masalah utama dalam budidaya tanaman pisang di Lampung, bahkan di Indonesia, adalah serangan Ralstonia sp. yang menyebabkan penyakit layu bakteri. Sejak penyakit ini ditemukan pertama kali oleh Ernst-Gaumann di Sulawesi tahun 1906 (Fegan, 2005), produksi tanaman pisang di Indonesia terus menurun dengan sangat tajam. Kehilangan hasil akibat penyakit ini dapat mencapai 10-42\% bahkan sampai $93,1 \%$ pada serangan yang berat (Rao, 1976; Rukmana, 1997).

Penyakit layu bakteri di Propinsi Lampung pertama kali ditemukan dan sekaligus bersifat epidemi di Kalianda, Lampung Selatan pada tahun 1993 (Mujim et al., 1993). Supriadi (2005) melaporkan bahwa penyakit ini menyebabkan sekitar 963.390 tanaman pisang di Lampung Selatan dan 1.101.000 tanaman pisang di Lampung Utara mati. Sampai saat ini, penyakit layu bakteri masih menjadi masalah karena belum dapat dikendalikan

Berdasarkan pengamatan di lapang, sering ditemukan bahwa dalam satu rumpun tanaman pisang terdapat satu atau beberapa tanaman yang tetap sehat sementara tanaman lainnya terserang bakteri Ralstonia sp. sampai mati. Tanaman yang sehat tersebut tampak seperti terlindungi dari serangan Ralstonia sp, padahal bakteri ini merupakan jenis bakteri soilborne yang dapat bertahan lama dan menyebar melalui tanah (Semangun, 2004; Goto, 1992).

Keberadaan tanaman sehat dekat tanaman lain yang sakit diduga karena di dalam tanah di sekitar perakaran tanaman pisang yang masih sehat tersebut terdapat mikroba yang berperan sebagai antagonis, sehingga tanah tersebut bersifat suppressive terhadap Ralstonia sp. (Campbell, 1989; Thurston, 1992; Agrios, 2005).

Arwiyanto (1997) melaporkan bahwa di sekitar perakaran gulma putri malu (Mimosa invisa) di Sumatera Utara terdapat populasi antagonis Bacillus sp dan pseudomonad fluorescent yang melimpah. Masih perlu diteliti apakah populasi antagonis yang melimpah ini juga terdapat di perakaran $M$. invisa yang ada di Lampung. Apabila dugaan itu benar, maka keberadaan gulma $M$. invisa yang sering ditemukan berada di sekitar pertanaman pisang ini diharapkan dapat menekan perkembangan bakteri Ralstonia sp. Penelitian ini dilakukan untuk mendapatkan dan mengetahui identitas bakteri antagonis Ralstonia sp. dari rhizosfer tanaman pisang sehat dari rumpun terinfeksi, sehingga nantinya akan

\footnotetext{
${ }_{1}^{1}$ Jurusan Proteksi Tanaman, Fakultas Pertanian, Universitas Lampung Jl. Prof. Sumantri Brojonegoro No. 1 Bandar Lampung 35145
} 
dapat digunakan sebagai agensia pengendali hayati penyakit layu bakteri pisang di lapangan.

\section{METODE PENELITIAN}

Survei lapang untuk koleksi isolat bakteri Ralstonia sp. dan bakteri antagonis dilakukan di Bandar Lampung, Lampung Selatan, Tanggamus, Lampung Timur dan Lampung Tengah. Pengujian isolat selanjutnya dilakukan di Laboratorium Penyakit Tumbuhan, Jurusan Proteksi Tanaman, Fakultas Pertanian Universitas Lampung. Pelaksanaan penelitian dimulai pada bulan Maret sampai dengan Oktober 2006.

\section{Eksplorasi dan isolasi bakteri yang berpotensi sebagai antagonis Ralstonia sp.}

Eksplorasi dilakukan di daerah-daerah yang banyak ditemukan tanaman pisang. Sampel tanah dan akar diambil dari risosfer tanaman pisang dan gulma putri malu (Mimmosa invisa) yang berada di sekitar pertanaman pisang. Setiap rhizosfer, diambil $1 \mathrm{~kg}$ tanah dan akar tanaman, masing-masing dari tiga titik lalu dikomposit. Tata laksana penelitian mengacu pada metode yang dilakukan oleh Arwiyanto (1997), dan Fahy \& Hayward (1983).

Sebanyak 10 gram tanah rhizosfer beserta akar tanaman pisang yang sehat dalam rumpun yang terserang dimasukkan ke dalam labu erlenmeyer 250 $\mathrm{ml}$ yang berisi $90 \mathrm{ml}$ air steril. Labu erlenmeyer tersebut kemudian digojok selama 30 menit lalu dilakukan pengenceran seri sampai dengan $10^{10}$ Dari hasil pengenceran ke $10^{9}$ dan $10^{10}$ diambil 100 mikroliter dan diratakan pada permukaan media King's B. Setelah inkubasi 48 jam pada suhu ruang, koloni bakteri yang membentuk zona penghambatan dipindahkan pada media yang sama dan diinkubasikan lagi selama 48 jam.

\section{Identifikasi bakteri yang berpotensi sebagai antagonis Ralstonia sp.}

Identifikasi isolat bakteri dilaksanakan dengan uji HR (hypersensitive reaction = reaksi hipersensitif) pada daun tembakau, uji gram, uji hidrolisis pati, uji warna koloni pada media YDC, uji fluoresensi bakteri, uji sifat oksidatif dan fermentatif, uji reduksi nitrat, dan uji hidrolisis gelatin. Tata laksana penelitian mengacu pada metode identifikasi yang dikembangkan oleh Schaad et al. (2001) dan Fahy \& Hayward (1983).

\section{Uji antagonisme bakteri antagonis terhadap Ralstonia sp. secara in vitro}

Penyiapan isolat Ralstonia sp. Isolat Ralstonia sp. yang akan digunakan dalam pengujian antagonisme merupakan koleksi Laboratorium Penyakit Tumbuhan, Fakultas Pertanian Universitas Lampung. Untuk lebih meyakinkan bahwa isolat bakteri Ralstonia sp. yang akan digunakan tidak kehilangan kemampuannya sebagai patogen, maka dilakukan pengujian Reaksi Hipersensitif (HR) dan dilanjutkan dengan uji patogenesitas pada tanaman pisang varietas Cavendish hasil kultur jaringan yang berumur sekitar 3 bulan.

Uji antagonisme. Isolat-isolat bakteri hasil eksplorasi yang menunjukkan potensi antagonisme ditumbuhkan pada media King's B yang telah dicampur dengan suspensi Ralstonia sp (200 mikroliter suspensi bakteri antagonis pada $4 \mathrm{ml}$ media King's B). Selanjutnya isolat-isolat antagonis tersebut ditumbuhkan pada setiap cawan petri sebanyak tiga titik per cawan, lalu diinkubasi selama 24 jam pada suhu ruang. Selanjutnya, isolat-isolat yang secara konsisten menghambat pertumbuhan Ralstonia sp. secara in vitro disimpan dalam agar miring yang ditutup dengan minyak parafin steril dan disimpan dalam almari pendingin untuk pengujian selanjutnya.

Pengamatan dilakukan terhadap pembentukan daerah bening atau zona penghambatan yang dihasilkan oleh isolat bakteri antagonis. Selanjutnya dilakukan pengukuran terhadap diameter daerah penghambatan dari masing-masing isolat bakteri. Data yang diperoleh diolah dengan sidik ragam (ANOVA) dan dilanjutkan dengan uji Beda Nyata Terkecil (BNT) dengan tingkat kepercayaan 5\%.

\section{HASIL DAN PEMBAHASAN}

Survei yang dilakukan di lima kabupaten (Lampung Selatan, Bandar Lampung, Tanggamus, Lampung Timur, dan Lampung Tengah) yang merupakan daerah pusat pertanaman pisang di Propinsi Lampung menunjukkan bahwa tidak di semua daerah pertanaman pisang terdapat gulma Mimosa invisa dan tanaman pisang terinfeksi penyakit layu bakteri. Gulma M. invisa terdapat di tiga 
kabupaten, yaitu Lampung Selatan, Bandar Lampung dan Lampung Tengah. Tanaman pisang yang terinfeksi penyakit layu bakteri terdapat di empat kabupaten, yaitu Lampung Selatan, Bandar Lampung, Tanggamus, dan Lampung Tengah, sedangkan di Kabupaten Lampung Timur tidak ditemukan adanya tanaman pisang yang terinfeksi oleh penyakit layu bakteri.

Tanaman pisang yang terinfeksi patogen layu bakteri ditunjukkan dengan menguningnya daun ke-3 atau ke-4 yang kemudian menyebabkan seluruh daunnya kering dan akhirnya tanaman mati (Gambar 1a). Bagian dalam buah tampak berwarna coklat kehitaman (Gambar 1b) disertai cairan agak kental yang berwarna coklat kekuningan. Apabila dibuat potongan melintang bagian batang, maka akan terlihat perubahan warna kecoklat-coklatan pada batang

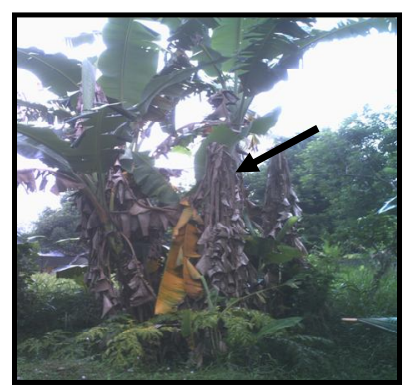

a

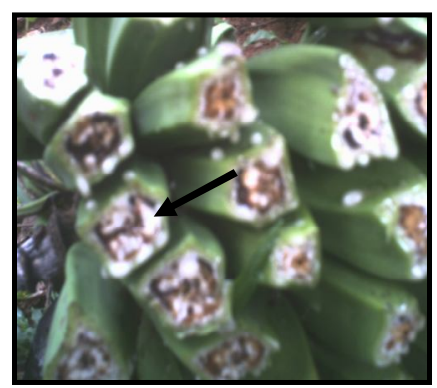

b

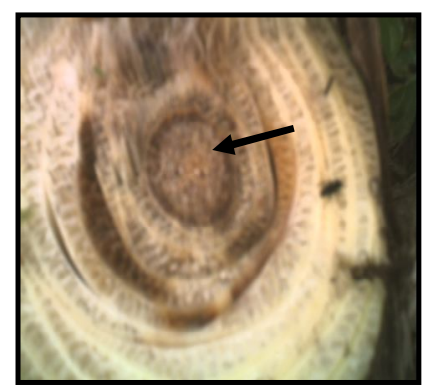

C

Gambar 1. Gejala layu bakteri pada tanaman pisang di lapang.

a. Gejala pada daun yang menguning dan akhirnya mengering

b. Gejala pada buah bagian dalam berwarna coklat kehitaman

c. Gejala pada batang yang berwarna coklat kehitaman

Tabel 1. Jumlah sampel dan kode titik sampel dari rhisosfer tanaman pisang dan gulma Mimosa invisa

\begin{tabular}{|c|c|c|c|c|c|}
\hline $\begin{array}{l}\mathrm{N} \\
\mathrm{o}\end{array}$ & Daerah survei & $\begin{array}{c}\text { Jumlah sampel } \\
\text { dari rizosfer } \\
\text { tanaman pisang }\end{array}$ & $\begin{array}{c}\text { Kode titik } \\
\text { sampel }\end{array}$ & $\begin{array}{c}\text { Juml.sampel } \\
\text { dari rizosfer } \\
\text { M. invisa }\end{array}$ & Kode titik sampel \\
\hline 1 & ampung Selatan & 6 & $\begin{array}{l}\text { K.1.1, K.2.1, } \\
\text { K.2.2, K.3.1, } \\
\text { K.3.2, K.4.1 }\end{array}$ & 1 & K.4.2 \\
\hline 2 & Bandar Lampung & 3 & $\begin{array}{l}\text { B.1.1, B.2.1, } \\
\text { B.3.1 }\end{array}$ & 1 & B.3.2 \\
\hline 3 & Tanggamus & 7 & $\begin{array}{l}\text { T.1.1, T.1.2, } \\
\text { T.1.3, T.1.4, } \\
\text { T.1.5, T.2.1 } \\
\text { T.2.2 }\end{array}$ & - & - \\
\hline 4 & Lampung Tengah & 2 & GS.1.1, GS.1.2 & 1 & GS.1.3 \\
\hline 5. & Lampung timur & - & - & - & - \\
\hline
\end{tabular}


Isolat bakteri yang berpotensi sebagai antagonis Ralstonia sp.

Isolat bakteri yang berpotensi sebagai antagonis ditunjukkan dengan terbentuknya zona bening di sekeliling bakteri tersebut (Gambar 2). Dari 18 sampel tanah yang berasal dari rhizosfer tanaman pisang, didapatkan sebanyak 82 isolat bakteri yang berpotensi sebagai antagonis, sedangkan dari 3 sampel tanah yang diambil dari rhizosfer gulma putri malu didapatkan 22 isolat.

\section{Identitas isolat bakteri yang berpotensi sebagai antagonis}

Hasil identifikasi terhadap keseluruhan isolat yang diperoleh (104 isolat) disajikan pada Tabel 2.

Berdasarkan hasil uji biokimia yang telah dilakukan dan kemudian dibandingkan dengan sumber pustaka (Schaad et al. , 2001 dan Fahy \& Hayward, 1983), dapat dikatakan bahwa 59 isolat tergolong dalam kelompok pseudomonad fluorescent, sedangkan 45 isolat lainnya belum dapat ditentukan kelompoknya.

Isolat yang termasuk dalam kelompok pseudomonad fluorescent menunjukkan ciri-ciri bersifat gram negatif, koloni berwarna putih pada medium YDC, bersifat positif pada uji OksidatifFermentatif, dan berpendar apabila dilihat di bawah sinar ultra violet (mengeluarkan pigmen fluorescen) (Schaad et al., 2001; Fahy \& Hayward, 1983).
Beberapa isolat yang masih belum teridentifikasi disebabkan karena setelah dicocokkan dengan guidelines yang ada, hasil uji biokimia yang didapatkan tidak menunjukkan ciri-ciri ke salah satu genus bakteri. Beberapa isolat menunjukkan hasil yang tidak konsisten ke salah satu kelompok bakteri. Kenyataan tersebut memunculkan dugaan bahwa isolat yang didapatkan masih terkontaminasi dengan jenis bakteri lain.

Jumlah isolat dari kelompok pseudomonad fluorescent ternyata lebih banyak, diduga karena kelompok bakteri ini mempunyai kemampuan berkompetisi dan menekan pertumbuhan patogen lain lebih kuat dibandingkan dengan kelompok antagonis yang lain. Isolat-isolat yang belum teridentifikasi merupakan isolat dengan ciri-ciri yang tidak semua ciri-cirinya memenuhi kriteria golongan tertentu, sehingga diperlukan uji lebih lanjut.

\section{Uji antagonisme bakteri antagonis terhadap Ralstonia sp. secara in vitro}

Isolat Ralstonia sp. Hasil pengujian ulang terhadap isolat Ralstonia sp. menunjukkan bahwa isolat tersebut mempunyai $H R$ positif yang ditunjukkan dengan terbentuknya daerah nekrotik pada daun tanaman tembakau 3 hari setelah diinjeksi dengan suspensi bakteri (Gambar 3a). Hasil uji patogenisitas pada tanaman pisang juga menunjukkan hasil positif, yaitu terlihat dari tanaman pisang yang layu setelah

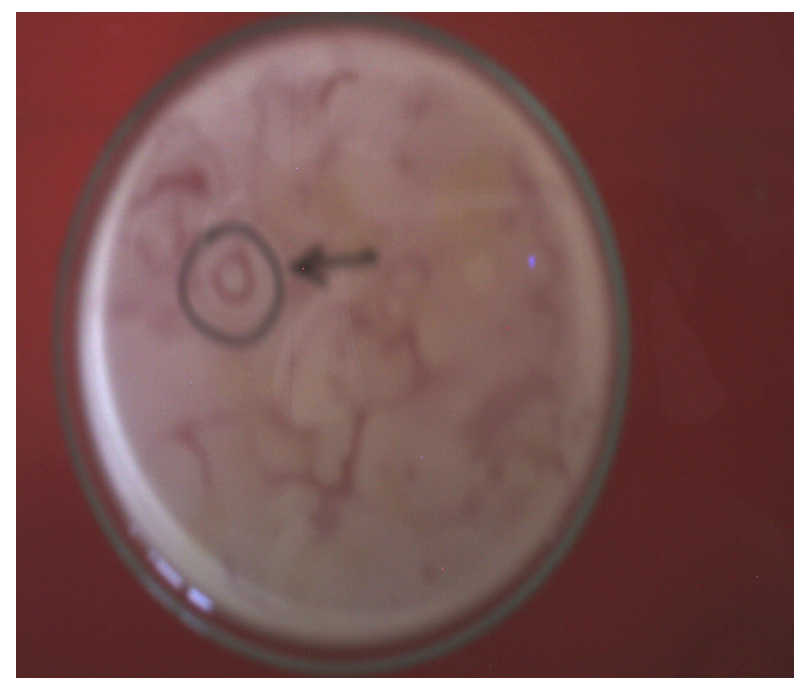

Gambar 2. Ciri-ciri isolat bakteri yang berpotensi sebagai antagonis 
Tabel 2. Hasil uji sifat gram dan uji biokimia

\begin{tabular}{|c|c|c|c|c|c|c|c|c|}
\hline No & Kode isolat & $\begin{array}{l}\text { Uji sifat } \\
\text { gram }\end{array}$ & $\begin{array}{c}\text { Uji } \\
\text { reduksi } \\
\text { nitrat }\end{array}$ & $\begin{array}{l}\text { Uji warna } \\
\text { koloni pada } \\
\text { media YDC }\end{array}$ & $\begin{array}{c}\text { Uji } \\
\text { hidrolisis } \\
\text { gelatin }\end{array}$ & $\begin{array}{c}\text { Uji } \\
\text { hidrolisis } \\
\text { pati }\end{array}$ & $\begin{array}{l}\text { Uji fluore- } \\
\text { sensi }\end{array}$ & $\begin{array}{l}\mathrm{Uji} \\
\mathrm{OF}\end{array}$ \\
\hline 1 & K.1.1 & - & - & PUTIH & + & + & + & + \\
\hline 2 & K.1.1.10 ${ }_{10}^{10}$ & + & - & PUTIH & + & + & + & + \\
\hline 3 & K.1.1.10 ${ }^{10}{ }_{1} \mathrm{~A}$ & + & - & PUTIH & + & + & + & + \\
\hline 4 & K.1.1.10 ${ }^{10}{ }_{1} \mathrm{~B}$ & - & - & PUTIH & - & - & - & + \\
\hline 5 & K.1.1.10 ${ }^{10}{ }_{1} \mathrm{C}$ & - & - & PUTIH & + & + & + & + \\
\hline 6 & K.1.1.10 ${ }^{10}{ }_{2} \mathrm{~A}$ & + & - & PUTIH & + & + & + & + \\
\hline 7 & K.1.1.10 ${ }^{10}{ }_{2}^{2} \mathrm{~B}$ & - & - & PUTIH & + & + & + & + \\
\hline 8 & K.2.1.10 ${ }_{2}^{9} \mathrm{~A}$ & - & - & PUTIH & + & + & + & - \\
\hline 9 & K.2.1.10 ${ }_{2}^{9}$ B & - & - & KUNING & + & + & + & + \\
\hline 10 & K.2.1.10 ${ }^{9}{ }_{2} \mathrm{C}$ & - & - & KUNING & + & + & + & + \\
\hline 11 & K.2.1.10 ${ }^{9}$ D & - & - & KUNING & + & + & + & + \\
\hline 12 & K.2.1.10 ${ }^{9}{ }_{2} \mathrm{E}$ & - & - & KUNING & + & + & + & - \\
\hline 13 & K.2.1.10 ${ }_{2}^{9} \mathrm{~F}$ & - & - & PUTIH & + & + & + & + \\
\hline 14 & K.2.1.10 ${ }^{9} \mathrm{G}$ & - & - & PUTIH & + & + & + & + \\
\hline 15 & K.2.1.10 ${ }^{9}{ }_{2} \mathrm{H}$ & - & - & KUNING & + & + & + & - \\
\hline 16 & K.2.1.10 ${ }_{2}^{9}{ }_{2} \mathrm{I}$ & - & - & PUTIH & + & + & + & - \\
\hline 17 & K.2.1.10 ${ }^{9}{ }_{2} \mathrm{~J}$ & - & - & PUTIH & + & + & + & + \\
\hline 18 & K.2.1.10 ${ }^{9} \mathrm{~K}$ & - & - & KUNING & + & + & + & + \\
\hline 19 & K.2.1.10 ${ }_{2}^{9} \mathrm{~L}$ & - & - & KUNING & + & + & + & + \\
\hline 20 & K.2.1.10 ${ }^{10}$ & - & - & KUNING & + & + & + & + \\
\hline 21 & K.2.1.10 ${ }_{3}^{10} \mathrm{~A}$ & + & - & KUNING & - & - & + & + \\
\hline 22 & K.2.1.10 ${ }^{10}{ }_{3} \mathrm{~B}$ & - & - & KUNING & + & - & + & - \\
\hline 23 & K.2.1.10 $1{ }^{10}{ }_{3} \mathrm{D}$ & - & - & KUNING & - & - & + & + \\
\hline 24 & К.3.2 & - & - & PUTIH & + & + & + & + \\
\hline 25 & K.3.2.10 ${ }^{10} \mathrm{~A}$ & - & - & PUTIH & + & + & + & + \\
\hline 26 & K.3.2.10 ${ }^{10}{ }_{1} \mathrm{~B}$ & - & - & PUTIH & - & + & + & + \\
\hline 27 & K.3.2.10 ${ }^{10}{ }_{1} \mathrm{C}$ & - & - & PUTIH & + & + & + & + \\
\hline 28 & K.3.2.10 ${ }^{10}{ }_{1} \mathrm{D}$ & - & - & PUTIH & + & + & + & - \\
\hline 29 & K.3.2.10 ${ }^{10}{ }_{1} \mathrm{E}$ & - & - & PUTIH & + & + & + & + \\
\hline 30 & K.3.2.10 ${ }^{10}{ }_{1} \mathrm{~F}$ & - & - & PUTIH & + & + & + & + \\
\hline 31 & K.3.2.10 ${ }^{10} \mathrm{G}$ & + & - & PUTIH & + & + & + & + \\
\hline 32 & K.3.2.10 ${ }^{10} \mathrm{~A}$ & - & - & PUTIH & + & + & + & + \\
\hline 33 & K.3.2.10 $1{ }^{10}{ }_{2} \mathrm{~B}$ & - & - & PUTIH & + & + & + & + \\
\hline 34 & K.3.2.10 ${ }^{10}{ }_{2} \mathrm{C}$ & + & - & PUTIH & + & + & + & + \\
\hline 35 & K.4.1 & - & - & PUTIH & + & + & + & + \\
\hline 36 & K.4.1.10 ${ }_{1}{ }_{\mathrm{A}}$ & - & - & PUTIH & + & + & + & + \\
\hline 37 & K. $4 \cdot 1 \cdot 10^{9}{ }_{2} \mathrm{~A}$ & - & - & PUTIH & + & + & + & + \\
\hline 38 & K.4.1.10 ${ }^{9}{ }_{2} \mathrm{~B}$ & + & - & PUTIH & + & - & + & + \\
\hline 39 & K.4.1.10 ${ }^{10} \mathrm{~A}$ & - & - & PUTIH & + & + & + & + \\
\hline 40 & K.4.1.10 ${ }^{10}{ }_{1} \mathrm{~B}$ & - & - & PUTIH & + & + & + & + \\
\hline 41 & K. $4 \cdot 1 \cdot 10^{10}{ }_{1} \mathrm{C}$ & + & - & PUTIH & + & + & + & + \\
\hline 42 & K.4.1.10 ${ }^{10}{ }_{1} \mathrm{D}$ & - & - & PUTIH & + & + & + & + \\
\hline 43 & K.4.1.10 ${ }^{10}{ }_{1} \mathrm{E}$ & + & - & PUTIH & + & - & + & + \\
\hline 44 & K.4.1.10 ${ }^{10}{ }_{1} \mathrm{~F}$ & + & - & PUTIH & + & + & + & + \\
\hline 45 & K.4.1.10 ${ }^{10}{ }_{1} \mathrm{G}$ & + & - & PUTIH & + & + & + & + \\
\hline 46 & K.4.2 & - & - & PUTIH & + & + & + & + \\
\hline 47 & K. $4 \cdot 2 \cdot 10^{10}{ }_{1} \mathrm{~A}$ & - & - & PUTIH & + & + & + & + \\
\hline
\end{tabular}


Tabel 2. Lanjutan

\begin{tabular}{|c|c|c|c|c|c|c|c|c|}
\hline No & Kode isolat & $\begin{array}{l}\text { Uji sifat } \\
\text { gram }\end{array}$ & $\begin{array}{c}\text { Uji } \\
\text { reduksi } \\
\text { nitrat }\end{array}$ & $\begin{array}{l}\text { Uji warna } \\
\text { koloni pada } \\
\text { media YDC }\end{array}$ & $\begin{array}{c}\text { Uji } \\
\text { hidrolisis } \\
\text { gelatin }\end{array}$ & $\begin{array}{c}\text { Uji } \\
\text { hidrolisis } \\
\text { pati }\end{array}$ & $\begin{array}{l}\text { Uji fluore- } \\
\text { sensi }\end{array}$ & $\begin{array}{l}\text { Uji } \\
\text { OF }\end{array}$ \\
\hline 48 & K.4.2.10 $10_{1}^{10}$ B & - & - & PUTIH & + & + & + & + \\
\hline 49 & B.1.1 & - & - & PUTIH & + & + & + & + \\
\hline 50 & B.1.1.10 ${ }_{1}^{9} \mathrm{~A}$ & + & - & PUTIH & + & + & + & + \\
\hline 51 & B.1.1.10 ${ }_{1}^{9} \mathrm{~B}$ & + & - & PUTIH & + & + & + & + \\
\hline 52 & B.1.1.10 ${ }^{9}{ }_{1} \mathrm{C}$ & - & - & PUTIH & + & + & + & - \\
\hline 53 & B.1.1.10 ${ }^{9}{ }_{1} \mathrm{D}$ & - & - & PUTIH & + & + & + & + \\
\hline 54 & B.1.1.10 ${ }^{9} \mathrm{E}$ & + & - & PUTIH & + & - & + & + \\
\hline 55 & B.1.1.10 $0_{91} \mathrm{~F}$ & + & - & PUTIH & + & + & + & + \\
\hline 56 & B.1.1.10 ${ }^{10}{ }_{1} \mathrm{~A}$ & - & - & PUTIH & + & + & + & + \\
\hline 57 & B.1.1.10 $10_{101}$ B & - & - & PUTIH & + & + & + & + \\
\hline 58 & B.1.1.10 ${ }^{10}{ }_{1} \mathrm{D}$ & - & - & PUTIH & + & + & + & + \\
\hline 59 & B.2.1.10 ${ }_{1}^{9} \mathrm{~A}$ & - & - & PUTIH & + & + & + & + \\
\hline 60 & B. $2 \cdot 1 \cdot 10^{9}{ }_{1} \mathrm{~B}$ & - & - & PUTIH & + & + & + & + \\
\hline 61 & B. $2 \cdot 1 \cdot 10^{9}{ }_{1} \mathrm{C}$ & - & - & PUTIH & + & + & + & + \\
\hline 62 & B.2.1.10 ${ }^{10}{ }_{1}$ & - & - & PUTIH & + & + & + & + \\
\hline 63 & B.3.1.10 ${ }^{10}{ }_{1} \mathrm{~A}$ & - & - & PUTIH & + & + & + & + \\
\hline 64 & B.3.1.10 ${ }^{10}{ }_{1} \mathrm{~B}$ & - & - & PUTIH & + & + & + & + \\
\hline 65 & B. $3.1 .10^{10}{ }_{1} \mathrm{C}$ & - & - & PUTIH & + & + & + & + \\
\hline 66 & B.3.1.10 ${ }^{10}{ }_{2} \mathrm{~A}$ & - & - & PUTIH & + & + & + & + \\
\hline 67 & B.3.1.10 $10_{2}^{10} \mathrm{~B}$ & - & - & PUTIH & + & + & + & + \\
\hline 68 & B.3.2.10 ${ }_{1}^{9} \mathrm{~A}$ & - & - & PUTIH & + & + & + & + \\
\hline 69 & B.3.2.10 ${ }^{9}{ }_{1}$ B & - & - & PUTIH & + & + & + & + \\
\hline 70 & B. $3 \cdot 2 \cdot 10^{9}{ }_{1} \mathrm{C}$ & + & - & PUTIH & + & + & + & + \\
\hline 71 & B.3.2.10 ${ }^{9}{ }_{1} \mathrm{D}$ & - & - & PUTIH & + & + & + & - \\
\hline 72 & B.3.2.10 ${ }^{9}{ }_{1} \mathrm{E}$ & - & - & PUTIH & + & - & + & + \\
\hline 73 & B.3.2.10 ${ }_{1}^{9} \mathrm{~F}$ & - & - & PUTIH & + & + & + & + \\
\hline 74 & B.3.2.10 ${ }_{3}^{9} \mathrm{~A}$ & - & - & PUTIH & + & + & + & + \\
\hline 75 & B.3.2.109 ${ }_{3}^{9}$ B & - & - & PUTIH & + & + & + & + \\
\hline 76 & B.3.2.10 ${ }^{9}{ }_{3} \mathrm{C}$ & - & - & PUTIH & + & + & + & - \\
\hline 77 & B.3.2.10 ${ }_{3}^{9} \mathrm{D}$ & - & - & PUTIH & + & + & + & + \\
\hline 78 & B.3.2.10 ${ }^{10}{ }_{1} \mathrm{~A}$ & + & - & PUTIH & + & & + & + \\
\hline 79 & B.3.2.10 ${ }_{10}^{10} \mathrm{~B}$ & - & - & PUTIH & + & + & + & - \\
\hline 80 & B.3.2.10 ${ }^{10}{ }_{1} \mathrm{C}$ & + & - & PUTIH & + & + & + & + \\
\hline 81 & T.1.1.109 & - & - & PUTIH & + & + & + & + \\
\hline 82 & T.1.1.10 ${ }_{1}^{10} \mathrm{~A}$ & + & - & PUTIH & + & + & + & + \\
\hline 83 & T.1.1.10 ${ }^{10}{ }_{1} \mathrm{~B}$ & + & - & PUTIH & + & + & + & - \\
\hline 84 & T.1.2.109 ${ }_{2} \mathrm{~A}$ & + & - & PUTIH & + & + & + & + \\
\hline 85 & T.1.2.10 ${ }_{2}^{9} \mathrm{~B}$ & + & - & PUTIH & + & + & + & + \\
\hline 86 & T.1.2.10 $10^{10}{ }_{1} \mathrm{~A}$ & - & - & PUTIH & + & + & + & + \\
\hline 87 & T.1.2.10. ${ }^{10}{ }_{1} \mathrm{~B}$ & + & - & PUTIH & + & + & + & - \\
\hline 88 & T.1.2.10 ${ }^{10}{ }_{1}^{1} \mathrm{C}$ & + & - & PUTIH & + & + & + & + \\
\hline 89 & T.1.2.10 ${ }_{3}^{10} \mathrm{~A}$ & - & - & PUTIH & + & + & + & - \\
\hline 90 & T.1.2.10 $10_{3}^{10} \mathrm{~B}$ & + & - & PUTIH & - & + & + & + \\
\hline 91 & T.3.1.109 ${ }_{1}^{9}$ & - & - & PUTIH & + & + & + & + \\
\hline 92 & GS.1.1.10 ${ }_{3}^{9}$ & - & - & PUTIH & + & + & + & + \\
\hline 93 & GS.1.1.10 ${ }^{10}{ }_{2} \mathrm{C}$ & - & - & PUTIH & + & + & + & + \\
\hline 94 & GS.1.2.10 ${ }_{3}^{9}$ & + & - & PUTIH & + & - & + & + \\
\hline
\end{tabular}


Tabel 2. Lanjutan

\begin{tabular}{ccccccccc}
\hline No & Kode isolat & $\begin{array}{c}\text { Uji } \\
\text { sifat } \\
\text { gram }\end{array}$ & $\begin{array}{c}\text { Uji } \\
\text { reduksi } \\
\text { nitrat }\end{array}$ & $\begin{array}{c}\text { Uji warna } \\
\text { koloni pada } \\
\text { media YDC }\end{array}$ & $\begin{array}{c}\text { Uji } \\
\text { hidrolisis } \\
\text { gelatin }\end{array}$ & $\begin{array}{c}\text { Uji } \\
\text { hidrolisis } \\
\text { pati }\end{array}$ & $\begin{array}{c}\text { Uji fluore- } \\
\text { sensi }\end{array}$ & $\begin{array}{c}\text { Uji } \\
\text { OF }\end{array}$ \\
\hline 95 & GS.1.2.10101 A & - & - & PUTIH & + & + & + & + \\
96 & GS.1.2.10101 B & - & - & PUTIH & + & + & + & + \\
97 & GS.1.2.10101 C & + & - & PUTIH & + & + & + & + \\
98 & GS.1.2.10102 & - & - & PUTIH & - & - & + & + \\
99 & GS.1.3.1091 & - & - & PUTIH & + & + & + & + \\
100 & GS.1.3.10101 B & - & - & PUTIH & + & + & + & + \\
101 & GS.1.3.10101 C & - & - & KUNING & + & + & + & + \\
102 & GS.1.3.10101 D & - & - & PUTIH & + & + & + & + \\
103 & GS.1.3.10101 E & - & - & PUTIH & + & + & + & + \\
104 & GS.1.3.10102 & - & - & KUNING & + & + & + & + \\
\hline
\end{tabular}

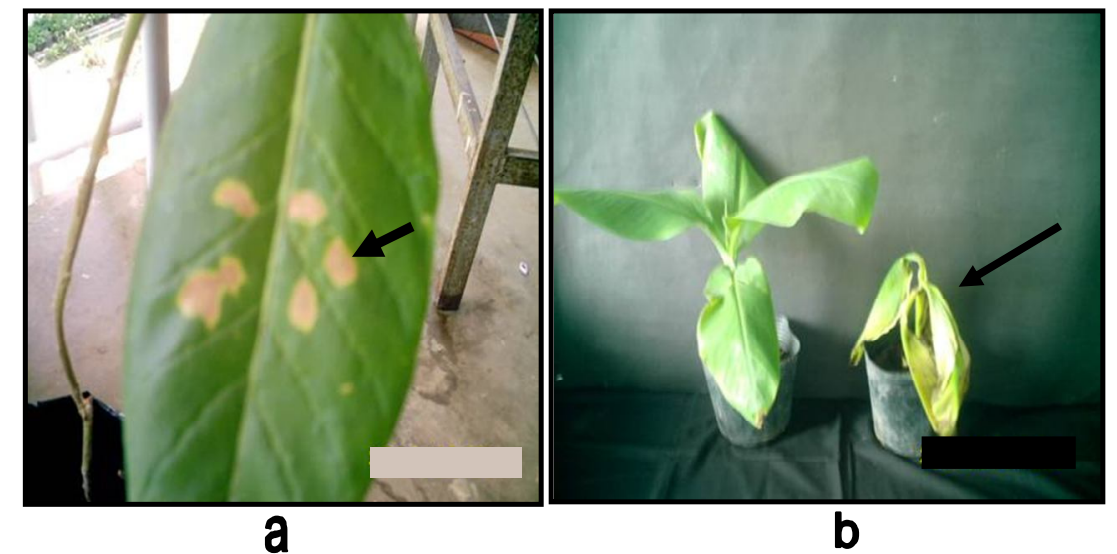

Gambar 3. a. Hasil positif pada uji reaksi hipersensitif pada tanaman tembakau, yang ditunjukkan dengan adanya daerah nekrotik

b. Hasil uji patogenesitas positif yang ditunjukkan dengan tanaman pisang yang layu setelah diinokulasi dengan suspensi bakteri Ralstonia sp. 5 hari setelah inokulasi (hsi)

diinokulasikan dengan suspensi Ralstonia sp. dan gejalanya yang sama dengan tanaman pisang yang terserang Ralstonia sp. di lapang (Gambar 3b). Hal itu menunjukkan bahwa bakteri Ralstonia sp yang ada tidak kehilangan kemampuannya sebagai patogen, sehingga bakteri tersebut dapat digunakan untuk pengujian antagonisme secara in vitro.

Uji antagonisme. Dari 104 isolat yang diuji, ternyata hanya sebanyak 41 isolat yang mempunyai kemampuan untuk menghambat pertumbuhan bakteri
Ralstonia sp.. Adanya sifat antagonisme ditunjukkan dengan terbentuknya zona bening di sekitar bakteri antagonis (Gambar 4) yang ditumbuhkan di media King's B yang telah dicampur dengan bakteri Ralstonia sp.. Ke-41 isolat bakteri antagonis menunjukkan kemampuan penghambatan yang bervariasi. Hal ini dapat dilihat dari ukuran diameter zona penghambatan yang terbentuk (Tabel 3). Hasil uji HR menunjukkan bahwa dari 41 isolat bakteri yang menunjukkan sifat antagonisme, sebanyak 31 isolat menunjukkan HR negatif, sedangkan 10 isolat menunjukkan HR positif. 


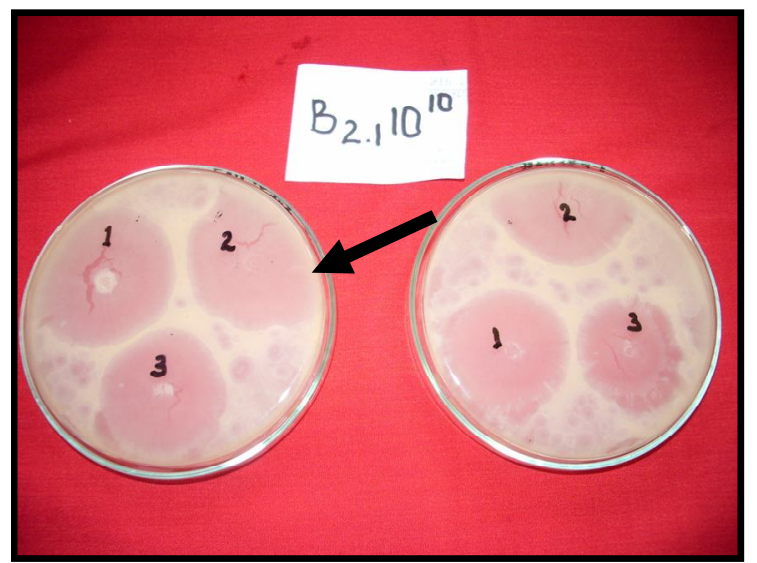

Gambar 4. Zona penghambatan yang terbentuk pada uji antagonisme bakteri antagonis dengan Ralstonia sp.

Tabel 3. Hasil Uji $H R$ (reaksi hipersensitif) dan rerata diameter zona penghambatan yang terbentuk pada uji antagonisme bakteri antagonis dengan Ralstonia sp.

\begin{tabular}{|c|c|c|c|c|}
\hline $\begin{array}{l}\text { Nomor } \\
\text { Isolat }\end{array}$ & Nama I s o l a t & $\begin{array}{l}\text { Asal isolat } \\
\text { dari Rizosfer }\end{array}$ & $\begin{array}{c}\text { Hasil Uji } \\
\text { HR }\end{array}$ & $\begin{array}{c}\text { Diameter } \\
\text { Penghambatan } \\
(\mathbf{m m})\end{array}$ \\
\hline 1 & Unidentified T1.1 $10^{10} 1 \mathrm{~A}$ & Pisang & - & 49,10 \\
\hline 2 & pseudomonad fluorescent B2.1 $10^{10}$ & Pisang & + & 44,28 \\
\hline 3 & pseudomonad fluorescent GS1.2 $10^{10} 1 \mathrm{~B}$ & Pisang & - & 30,91 \\
\hline 4 & pseudomonad fluorescent B3.2 109 $1 \mathrm{~A}$ & Putri malu & - & 22,04 \\
\hline 5 & pseudomonad fluorescent $\mathrm{K} 3.210^{10} 1 \mathrm{~A}$ & Pisang & - & 16,98 \\
\hline 6 & pseudomonad fluorescent K1.1 $10^{10} 2 \mathrm{~B}$ & Pisang & + & 15,80 \\
\hline 7 & Unidentified B3.2 $10^{10} 1 \mathrm{~B}$ & Putri malu & - & 15,58 \\
\hline 8 & pseudomonad fluorescent T1.1 $10^{9} 2$ & Pisang & - & 9,31 \\
\hline 9 & pseudomonad fluorescent B2.1 $10^{9} 1 \mathrm{C}$ & Pisang & - & 14,05 \\
\hline 10 & Unidentified GS1.2 $10^{9} 3$ & Pisang & + & 13,79 \\
\hline 11 & pseudomonad fluorescent B1.1 & Pisang & - & 14,03 \\
\hline 12 & pseudomonad fluorescent K4.1 $10^{9} 2 \mathrm{~A}$ & Pisang & + & 12,22 \\
\hline 13 & pseudomonad fluorescent $\mathrm{K} 4.210^{10} 1 \mathrm{~A}$ & Putri malu & - & 13,39 \\
\hline 14 & Unidentified GS $1.210^{10} 2$ & Pisang & + & 10,66 \\
\hline 15 & pseudomonad fluorescent $\mathrm{K} 4.110^{10} 1 \mathrm{~B}$ & Pisang & - & 10,54 \\
\hline 16 & Unidentified $\mathrm{K} 4.110^{10} 1 \mathrm{C}$ & Pisang & - & 10,84 \\
\hline
\end{tabular}


Tabel 3. Lanjutan

\begin{tabular}{|c|c|c|c|c|}
\hline $\begin{array}{l}\text { Nomor } \\
\text { Isolat }\end{array}$ & Nama I s o l a t & $\begin{array}{c}\text { Asal isolat } \\
\text { dari Rizosfer }\end{array}$ & $\begin{array}{c}\text { Hasil Uji } \\
\text { HR }\end{array}$ & $\begin{array}{c}\text { Diameter } \\
\text { Penghambatan } \\
(\mathrm{mm})\end{array}$ \\
\hline 17 & pseudomonad fluorescent GS1.1 $10^{9} 3$ & Pisang & + & 9,92 \\
\hline 18 & pseudomonad fluorescent K4.1 $10^{9} 1 \mathrm{~A}$ & Pisang & - & 9,71 \\
\hline 19 & pseudomonad fluorescent K3.2 $10^{10} 1 \mathrm{~B}$ & Pisang & - & 9,63 \\
\hline 20 & pseudomonad fluorescent T1.1 $10^{9} 2$ & Pisang & - & 14,23 \\
\hline 21 & pseudomonad fluorescent GS1.1 $10^{10} 2 \mathrm{C}$ & Pisang & - & 9,16 \\
\hline 22 & pseudomonad fluorescent B2.1 $10^{9} 1 \mathrm{~A}$ & Pisang & - & 8,53 \\
\hline 23 & Unidentified GS $1.210^{10} 1 \mathrm{C}$ & Pisang & + & 8,63 \\
\hline 24 & pseudomonad fluorescent GS1.3 $10^{10} 1 \mathrm{~B}$ & Putri malu & + & 8,27 \\
\hline 25 & pseudomonad fluorescent B3.1 $10^{10} 1 \mathrm{C}$ & Pisang & - & 8,10 \\
\hline 26 & pseudomonad fluorescent K3.2 $10^{10} 1 \mathrm{~F}$ & Pisang & - & 7,74 \\
\hline 27 & pseudomonad fluorescent GS1.3 $10^{10} 1 \mathrm{E}$ & Putri malu & + & 7,41 \\
\hline 28 & pseudomonad fluorescent K4.1 & Pisang & - & 7,55 \\
\hline 29 & pseudomonad fluorescent $\mathrm{K} 4.110^{10} 1 \mathrm{~A}$ & Pisang & - & 6,18 \\
\hline 30 & pseudomonad fluorescent B3.2 $10^{9} 3 \mathrm{D}$ & Putri malu & - & 6,08 \\
\hline 31 & Unidentified B3.2 $10^{9} 3 \mathrm{~B}$ & Pisang & - & 5,24 \\
\hline 32 & pseudomonad fluorescent $\mathrm{K} 3.210^{10} 1 \mathrm{E}$ & Pisang & - & 5,07 \\
\hline 33 & pseudomonad fluorescent B1.1 $10^{10} 1 \mathrm{D}$ & Pisang & - & 4,66 \\
\hline 34 & pseudomonad fluorescent $\mathrm{K} 3.210^{10} 2 \mathrm{~B}$ & Pisang & - & 4,34 \\
\hline 35 & pseudomonad fluorescent B1.1 $10^{10} 1 \mathrm{~B}$ & Pisang & - & 4,03 \\
\hline 36 & pseudomonad fluorescent B3.2 $10^{9} 1 \mathrm{~B}$ & Putri malu & + & 3,67 \\
\hline 37 & pseudomonad fluorescent K1.1 & Pisang & - & 3,61 \\
\hline 38 & pseudomonad fluorescent B2.1 $10^{9} 1 \mathrm{C}$ & Pisang & - & 3,49 \\
\hline 39 & pseudomonad fluorescent GS1.2 $10^{10} 1 \mathrm{~A}$ & Pisang & - & 4,10 \\
\hline 40 & Unidentified B3.2 $10^{9} 1 \mathrm{D}$ & Putri malu & - & 2,18 \\
\hline 41 & pseudomonad fluorescent K2.1 $10^{9} 2 \mathrm{~J}$ & Pisang & - & 1,77 \\
\hline
\end{tabular}

Rata-rata zona penghambatan terbentuk pada 24 jam setelah inokulasi (jsi), tetapi ada juga beberapa isolat bakteri antagonis yang membentuk zona bening pada 48 jsi. Adanya perbedaan waktu dalam pembentukan zona penghambatan ini diduga karena kemampuan antagonis isolat bakteri antagonis yang berbeda-beda. Pertambahan ukuran zona penghambatan yang terbentuk juga tidak sama, tetapi pada pengamatan hari ke-5 (120 jsi) ukuran zona penghambatan tidak mengalami pertambahan lagi.

Berdasarkan hasil analisis statistik, isolat-isolat bakteri antagonis yang diuji tidak menunjukkan perbedaan yang nyata, artinya, isolat-isolat bakteri antagonis yang diuji tersebut mempunyai kemampuan yang relatif sama dalam menghambat pertumbuhan Ralstonia sp. secara in vitro. 
Hasil pengamatan terhadap diameter zona penghambatan menunjukkan bahwa isolat unidentified T1.1 $10^{10} 1 \mathrm{~A}$ (U T1.1 $\left.10^{10} 1 \mathrm{~A}\right)$, pseudomonad fluorescent GS1.2 $10^{10}$ 1B (Pf GS1.2 10 $10^{10}$ ) dan pseudomonad fluorescent B3.2 $10^{9} 1 \mathrm{~A}$ (Pf B3.2 $10^{9}$ 1A) membentuk daerah penghambatan yang relatif lebih besar dibandingkan dengan isolat lainnya. Oleh karena itu ketiga isolat tersebut dianggap mempunyai kemampuan antagonisme yang lebih baik. Ketika ketiga isolat bakteri antagonis tersebut ditumbuhkan pada media yang sama, ternyata antar ketiganya tidak saling menghambat, yang ditunjukkan oleh tidak terbentuknya zona bening di sekitar bakteri antagonis (Gambar 5). Dengan demikian, ketiga isolat tadi dapat dikatakan mempunyai potensi yang baik sebagai antagonis. Selain itu, ketiga antagonis tersebut kemungkinan dapat diaplikasikan secara bersamasama atau berkombinasi untuk mendapatkan efek penghambatan yang lebih besar.

\section{SIMPULAN}

Berdasarkan uraian hasil penelitian yang ada maka dapat disimpulkan bahwa :

1. Tidak semua bakteri yang berpotensi sebagai antagonis dapat menghambat Ralstonia sp. Dari 104 isolat yang diperoleh, 41 isolat menunjukkan kemampuan untuk menghambat pertumbuhan Ralstonia sp. secara in vitro.

2. Sebanyak 33 isolat dari 41 isolat bakteri antagonis yang didapatkan termasuk dalam kelompok pseudomonad flourescent.

3. Tiga isolat yang mempunyai kemampuan penghambatan terbaik terhadap Ralstonia sp. adalah Unidentified T1.1 $10^{10}$ 1A (U T1.1 $10^{10}$ 1A), pseudomonad fluorescent GS1.2 $10^{10} 1 \mathrm{~B}(\mathrm{Pf}$ GS1.2 10 10 1B) dan pseudomonad fluorescent B3.2 $10^{9} 1 \mathrm{~A}\left(\mathrm{Pf} \mathrm{B} 3.210^{9} 1 \mathrm{~A}\right)$.

\section{SANWACANA}

Penulis mengucapkan terima kasih kepada Jurusan Proteksi Tanaman, Fakultas Pertanian Universitas Lampung yang telah memberikan bantuan dana penelitian melalui Program Hibah Penelitian PHK A2 Tahun Anggaran 2006. Ucapan terima kasih juga disampaikan kepada Dwi Noviyanti, S.P., Wahyu Utaminingsih, S.P., Nurdiana, S.P., dan semua pihak atas bantuan yang telah diberikan selama pelaksanaan penelitian ini.

\section{DAFTAR PUSTAKA}

Aeny, T. N. 1999. Pengaruh Bakterisida dan Fungisida terhadap Intensitas Penyakit Layu Bakteri (Pseudomonas solanacearum) pada Pisang. J. Pen. Peng. Wil. Lahan Kering, No. $22 / 23$.

Agrios, G.N. 2005. Plant Pathology. Academic Press. New York

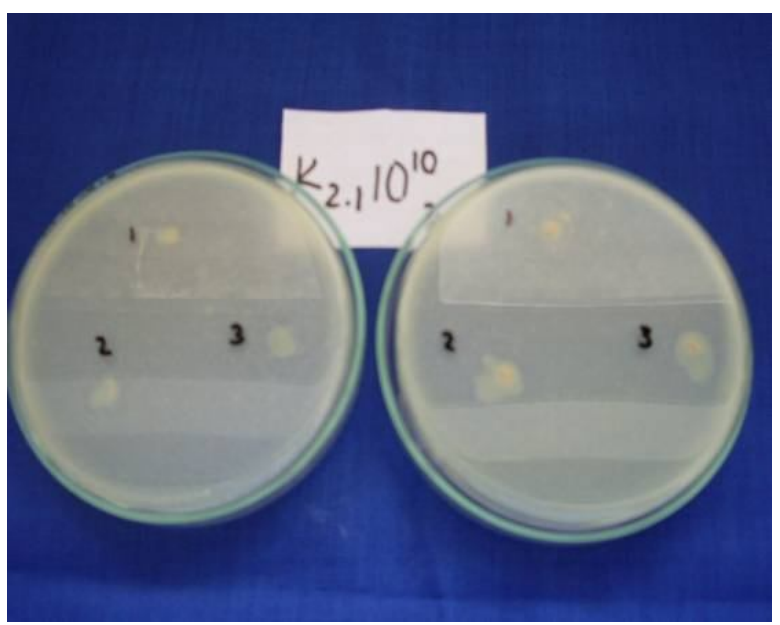

Gambar 5. Hasil uji antagonisme antar isolat antagonis tidak menunjukkan adanya zona penghambatan 
Arwiyanto. 1997. Pengendalian Hayati Penyakit Layu bakteri Tembakau : 1. Isolasi Bakteri Antagonis. Jurnal Perlindungan Tanaman Indonesia 3(1) : $54-60$

Campbell, R. 1989. Biological Control of Microbial Plant Pathogens. Cambrige University Press

Eden-Green, S. J. 1994. Banana Blood Disease. http // : www. Inibab. org / publication /factsheet/ fiche_3eng. Pdf

Fahy, P.C. \& A.C. Hayward. 1983. Media and methods for Isolation and Diagnostic Tests. In : Fahy, P.C \& G.J. Persley. Plant Bacterial Disease A Diagnostic Guide. Academic Press.

Fegan, M. 2005. Bacterial Wilt Disease of Banana in : In: C. Allen, P. Prior, A.C. Hayward. Bacterial Wilt Disease and the Ralstonia solanacearum Species Complex. American Phytopathological Society Press, Minnesota.

Goto, M. 1992. Fundamentals of Bacterial Plant Pathology.Academic Press. New York

Mujim, S., A. Gafur, T.N. Aeny, \& I.G. Swibawa. 1993. Pengamatan Penyakit Pisang di Kalianda, Lampung Selatan: Laporan Kemajuan. 6 hlm. (tidak dipublikasikan)
Rao, M.V.B., 1976. Bacterial Wilt of Tomato and Eggplant in India. In Proc. 1st International Planning Conference and Workshop on Ecology and Control of Bacterial Wilt Caused by Pseudomonas solanacearum, New Delhi, India.

Rukmana. 1997. Penyakit Tanaman dan Teknik Pengendalian. Kanisius. Jakarta

Schaad, N.W, J.B Jones and W. Chun. 2001. Laboratory Guide For Identification of Plant Pathogenic Bacteria.APS Press.Minnesota.

Semangun, H. 2004. Penyakit-Penyakit Tanaman Hortikultura di Indonesia. Gadjah Mada University Press. Yogyakarta.

Supriadi. 1999. Karateristik Kultur dan Patogenesitas Isolat Ralstonia solanacearum Penyebab Penyakit Darah Pada Tanaman Pisang. Jurnal Hortikultura 9(2) : $129-136$

Supriadi. 2005. Present Status of Blood disease In Indonesia. In: C. Allen, P. Prior, A.C. Hayward. Bacterial Wilt Disease and the Ralstonia solanacearum Species Complex. American Phytopathological Society Press, Minnesota.

Thurston, H.D. 1992. Sustainable Practise for Plant Disease Management in Traditional Farming Systems. Oxford \& IBH Publishing Co. Pvt. Ltd. 